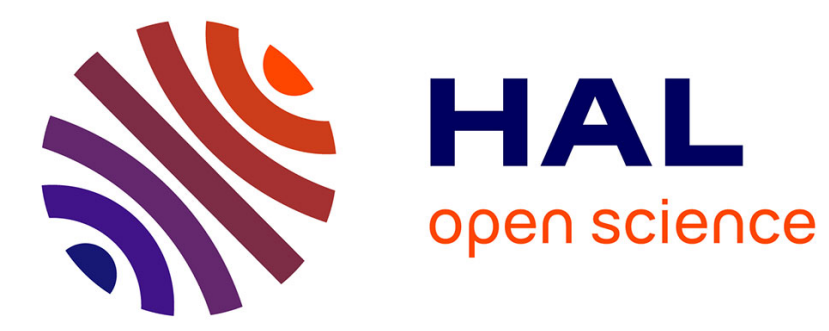

\title{
Adipose Tissue Macrophages: MR Tracking to Monitor Obesity-associated Inflammation 1
}

\author{
Alain Luciani, Sophie Dechoux, Vanessa Deveaux, Marie Poirier-Quinot, \\ Nathalie Luciani, Michael Lévy, Sébastien Ballet, Sylvie Manin, Christine \\ Péchoux, Gwennhael Autret, et al.
}

\section{To cite this version:}

Alain Luciani, Sophie Dechoux, Vanessa Deveaux, Marie Poirier-Quinot, Nathalie Luciani, et al.. Adipose Tissue Macrophages: MR Tracking to Monitor Obesity-associated Inflammation 1. Radiology, 2012, 263, 10.1148/radiol.12111957 . hal-02269994

\section{HAL Id: hal-02269994 https://hal.science/hal-02269994}

Submitted on 23 Aug 2019

HAL is a multi-disciplinary open access archive for the deposit and dissemination of scientific research documents, whether they are published or not. The documents may come from teaching and research institutions in France or abroad, or from public or private research centers.
L'archive ouverte pluridisciplinaire HAL, est destinée au dépôt et à la diffusion de documents scientifiques de niveau recherche, publiés ou non, émanant des établissements d'enseignement et de recherche français ou étrangers, des laboratoires publics ou privés. 
archives-ouvertes

\title{
Adipose Tissue Macrophages: MR Tracking to Monitor Obesity-associated Inflammation 1
}

\author{
Alain Luciani, Sophie Dechoux, Vanessa Deveaux, Marie Poirier-Quinot, \\ Nathalie Luciani, Michael Lévy, Sébastien Ballet, Sylvie Manin, Christine \\ Péchoux, Gwennhael Autret, et al.
}

\section{To cite this version:}

Alain Luciani, Sophie Dechoux, Vanessa Deveaux, Marie Poirier-Quinot, Nathalie Luciani, et al.. Adipose Tissue Macrophages: MR Tracking to Monitor Obesity-associated Inflammation 1. radiology.rsna.org n Radiology, 2012, 263. hal-02269994

\section{HAL Id: hal-02269994 \\ https://hal.archives-ouvertes.fr/hal-02269994}

Submitted on 23 Aug 2019

HAL is a multi-disciplinary open access archive for the deposit and dissemination of scientific research documents, whether they are published or not. The documents may come from teaching and research institutions in France or abroad, or from public or private research centers.
L'archive ouverte pluridisciplinaire HAL, est destinée au dépôt et à la diffusion de documents scientifiques de niveau recherche, publiés ou non, émanant des établissements d'enseignement et de recherche français ou étrangers, des laboratoires publics ou privés. 
Adipose Tissue Macrophages:

MR Tracking to Monitor

Obesity-associated Inflammation ${ }^{1}$

Alain Luciani, MD, PhD

Sophie Dechoux, MD

Vanessa Deveaux, PhD

Marie Poirier-Quinot, PhD

Nathalie Luciani, PhD

Michael Levy, PhD

Sebastien Ballet, PhD

Sylvie Manin

Christine Péchoux, PhD

Gwennhael Autret, PhD

Olivier Clément, MD, PhD

Alain Rahmouni, MD, PhD

Ariane Mallat, MD, PhD

Claire Wilhelm, PhD

Sophie Lotersztajn, PhD

Florence Gazeau, PhD
${ }^{1}$ From INSERM, U955, Equipe 17, Créteil, 94000, France (A.L., S.D., V.D., S.M., A.M., S.L.); Université Paris-Est, Faculté de Médecine, UMR-S955, Créteil, France (A.L., S.D., V.D., S.M., A.M., S.L.); Department of Medical Imaging (A.L., A.R.) and Department of Hepatology and Gastroenterology (A.M., S.L.), AP-HP, Groupe Henri Mondor Albert Chenevier, CHU Henri Mondor, 51 Avenue du Marechal de Lattre de Tassigny, F-94010 Créteil, France; U2R2M (CNRS UMR8081), Université Paris Orsay, Orsay, France (M.P.); Laboratoire MSC, UMR 7057, CNRS/Université Paris Diderot, Paris, France (N.L., M.L., C.W., F.G.); Guerbet Research Center, Aulnay-sous-Bois, France (S.B.); MIMA2-UR1196 Génomique et Physiologie de la Lactation, INRA, Plateau de Microscopie Electronique, Jouy-en-Josas, France (C.P.); and INSERM Unite U 970, Equipe 2, PARCC, HEGP, Paris, France (G.A., O.C.). Received September 13, 2011; revision requested October 21; revision received January 13, 2012; accepted January 26; final version accepted February 14. Supported by the INSERM and the Université Paris-Est. S.D. supported by a grant from Assistance Publique Hôpitaux de Paris-GH Henri Mondor Albert Chenevier. S.L. supported by grants from the Agence Nationale de la Recherche. Address correspondence to A.L. (e-mail: alain.luciani@ hmn.aphp.fr).

' RSNA, 2012
Purpose:

Materials and Methods:

Results:

Conclusion:

P904 USPIO-enhanced MR imaging is potentially a tool for noninvasive assessment of adipose tissue inflammation during experimental obesity. These results provide the basis for translation of MR imaging into clinical practice as a marker of patients at risk for metabolic syndrome.

๑ RSNA, 2012

Supplemental material: http://radiology.rsna.org/lookup /suppl/doi:10.1148/radiol.12111957/-/DC1 
0 besity-related disorders-including type 2 diabetes, cardiovascular disease, hypertension, and nonalcoholic fatty liver disease (1) - are reaching epidemic proportions worldwide (2). Obesity is associated with chronic low-grade inflammation of the adipose tissue mediated by adipose tissue macrophage infiltration (3). The adipose tissue produces proinflammatory cytokines and chemoattractant cytokines that accompany the development of insulin resistance $(4,5)$. Accumulating evidence suggests that macrophage infiltration within expanding adipose tissue directly contributes to the increased levels of inflammatory markers observed in obese patients $(6,7)$. In adipose tissue, fat-laden adipocytes promote the recruitment of adipose tissue macrophage and further amplification of local inflammation (8). Hence, adipose tissue macrophages play a key role in the inflammatory response to obesity and in the development of obesity-related comorbidities (9). To date, however, noninvasive detection of macrophage-related inflammation accompanying obesity remains indirect and fails to quantify macrophage burden within adipose tissue (10). Because adipose tissue macrophages play a pivotal role in the initiation of obesity-related disorders, their early detection could be useful in preclinical diagnosis of this syndrome. Preclinical and clinical

\section{Advances in Knowledge}

- Ultrasmall superparamagnetic iron oxide-enhanced MR imaging after P904 intravenous injection enables imaging and quantitation of adipose tissue macrophages in a rodent model of obesity.

- MR imaging signal variance in adipose tissue is correlated to P904 uptake $(r=0.87)$ and to macrophage-related adipose tissue inflammation characterized by immunohistochemical F4/80 staining $(r=0.60)$ and expression of CCl2, Tnf $\alpha$, and Emr1 messenger RNA proinflammatory markers $(r=0.55,0.56$, and 0.58 , respectively). studies have suggested that ultrasmall superparamagnetic iron oxide (USPIO) can enable macrophage-specific imaging at a cellular level (11). Used as contrast agents, USPIOs are taken up by macrophages, which can be detected at magnetic resonance (MR) imaging. Hence, macrophage infiltration within atherosclerotic vascular walls can be detected, localized, and quantified at USPIO-enhanced MR imaging (12). The use of a USPIO contrast agent made of a maghemite core coated with a lowmolecular-weight amino-alcohol derivative of glucose (P904) has recently been reported. Because of its high relaxivity and rapid blood-pool clearance, this contrast agent has been used for MR imaging detection of macrophages within atherosclerotic aortic walls of hyperlipidemic rabbits (13) or in apolipoprotein E mice models (14). We hypothesized that intravenously injected P904 particles could be taken up by adipose tissue macrophages and could hence influence the signal intensity of adipose tissue in obese mice.

Our purpose was to investigate whether cellular imaging by using USPIO-enhanced MR imaging can allow detection and quantification of adipose tissue macrophage-related inflammation within adipose tissue in a mouse model.

\section{Materials and Methods}

One author (S.B.), an employee of Guerbet (Aulnay-sous-Bois, France), provided P904 contrast agent for the experiments. The other authors, who are not employees of or consultants for Guerbet, retained full control of the data and information submitted for publication.

\section{Animals}

Experimental protocols were conducted in accordance with French government policies (Veterinary Services of Health and Animal Production, French Ministry of Agriculture). We selected a leptin-deficient obese mouse (ob/ob) model that shows progressive obesity, insulin resistance, and dyslipidemia as a function of age (15). A total of 34 mice (Janvier, Le Genest-Saint-Isle, France) at 7,10 , and 14 weeks old were used for animal experiments. Twenty-one mice were injected with P904 (10 ob/ob and $11 \mathrm{ob} /+$ ), and 13 mice were used as noninjected controls (seven $o b / o b$ and six $o b /+)$. Seven- $(n=4), 10-(n=2)$, and 14-week-old $(n=4) o b / o b$ mice underwent P904 injection, while 7 - $(n=$ 4 ) and 10-week-old ob/ob mice $(n=3)$ served as noninjected controls. Seven$(n=4), 10-(n=3)$, and 14-week-old ( $n$ =4) $o b /+$ mice underwent P904 injection, while 7- $(n=4)$ and 10-week-old $(n=2) o b /+$ mice served as noninjected controls. MR imaging was performed 10 days after P904 injection (Fig 1).

\section{Imaging Agent}

USPIO P904 was obtained from Guerbet. USPIO P904 is made of a maghemite core coated with a low-molecular-weight amino-alcohol derivative of glucose (P904) with a hydrated particle diameter of $21 \mathrm{~nm}$. After intravenous injection of $200 \mu \mathrm{mol}$ of iron per kilogram of body weight of P904 in healthy mice, the known half-life $\alpha$ is 15.7 minutes and half-life $\beta$ is 942.8 minutes, accounting for a clearance of $0.73 \mathrm{~mL} /$ min · kg. A dose of $1000 \mu \mathrm{mol}$ of iron per kilogram of $\mathrm{P} 904$ was used in this experimental setup. The P904 was injected intravenously through the retroorbital sinus vein.

\section{Published online before print}

10.1148/radiol.12111957 Content code: BQ

Radiology 2012; 263:786-793

\section{Abbreviations:}

$E P R=$ electron paramagnetic resonance

USPIO = ultrasmall superparamagnetic iron oxide

\section{Author contributions:}

Guarantors of integrity of entire study, A.L., G.A., S.L.; study concepts/study design or data acquisition or data analysis/interpretation, all authors; manuscript drafting or manuscript revision for important intellectual content, all authors; manuscript final version approval, all authors; literature research, A.L., S.D., V.D., M.L., C.W., S.L., F.G.; experimental studies, A.L., S.D., V.D., M.P., N.L., M.L., S.M. C.P., G.A., O.C., C.W., F.G.; statistical analysis, A.L., S.D., V.D.; and manuscript editing, A.L., S.D., V.D., N.L., M.L., S.B., C.P., O.C., A.R., A.M., F.G.

Potential conflicts of interest are listed at the end of this article.

See also Science to Practice in this issue. 


\section{Figure 1}

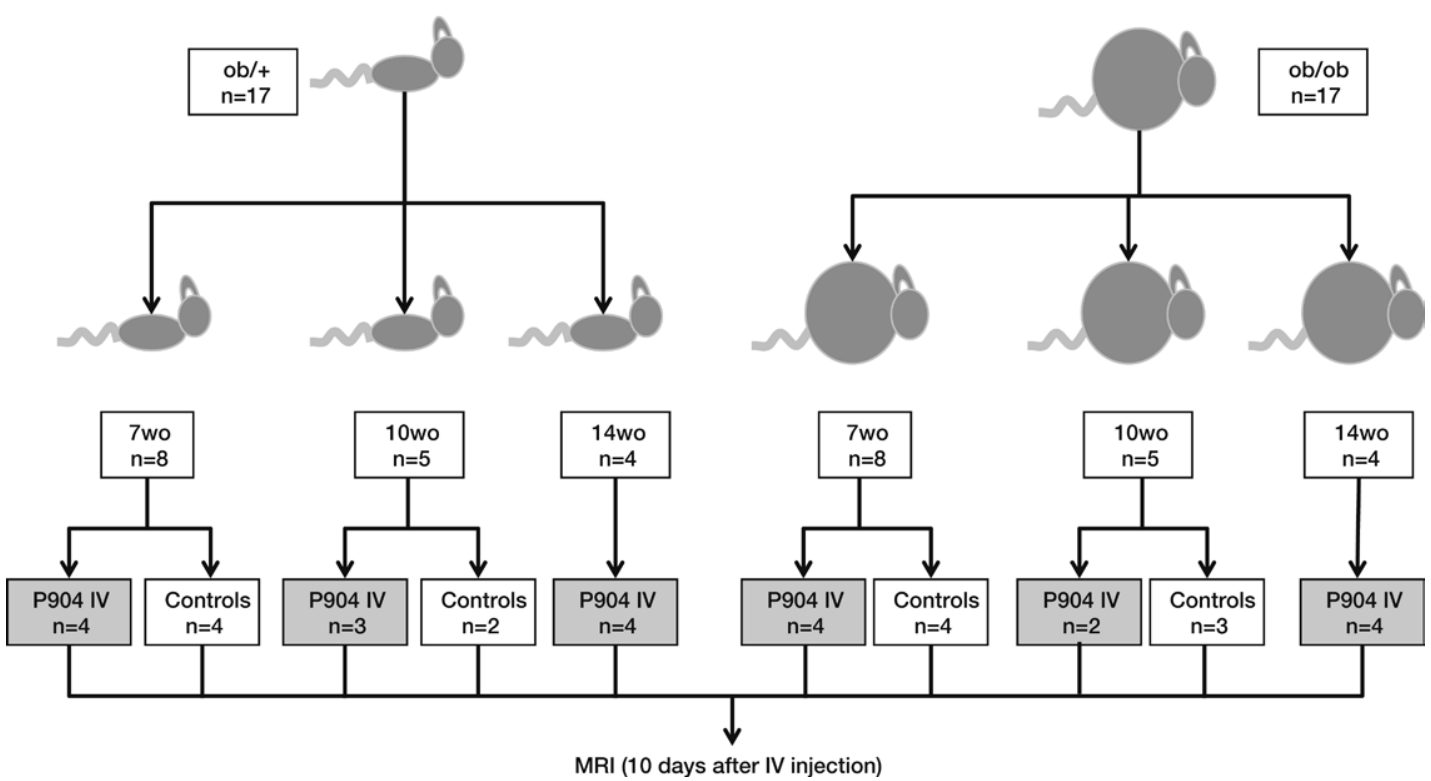

Figure 1: Diagram shows a total of 34 mice included in the experimental setup, including $17 \mathrm{ob} / \mathrm{ob}$ and $17 \mathrm{ob} /+$ mice of 7,10 , and 14 weeks old (wo). A total of 21 mice were injected with P904 (10 ob/ob and $11 \mathrm{ob} /+)$, and 13 mice were used as noninjected controls (seven $o b / o b$ and six $o b /+$ ). $I V=$ intravenous.

\section{Cellular Imaging by Using \\ MR Imaging}

MR imaging was performed with a 4.7-T small-animal MR imaging system (BioSpec USR47/40; Bruker BioSpin, Billerica, Mass) with a 40-cm bore and a dedicated coil. All animals were weighed on the day of MR imaging procedures. Anesthesia was achieved by using continuous isoflurane inhalation (Aerrane; Baxter, Maurepas, France) monitored with a respiratory trigger and was maintained during all MR imaging procedures. A three-dimensional $\mathrm{T}^{*}$-weighted gradient-echo sequence was selected owing to its sensitivity to USPIO-induced susceptibility artifacts (13) (repetition time, 20 msec; echo time, 5 msec; $40 \times 40 \times$ 30-mm field of view; flip angle, $1.5^{\circ} ; 400$ $\times 400 \times 256$ matrix). A mean of 200 sections (range, 115-256 sections) were acquired, encompassing both subcutaneous and epididymal adipose tissue.

\section{Image Analysis}

Regions of interest were placed by a radiologist (A.L., with 10 years of experience in abdominal MR imaging) in the epididymal adipose tissue on two different sections in each animal. Sections were selected in the center of the subcutaneous adipose tissue volume. Regions of interest were manually positioned within the epididymal adipose tissue, avoiding vessels, subcutaneous adipose tissue, and skin, allowing computation of mean signal intensity within the epididymal adipose tissue and corresponding standard deviation. The mean sizes of epididymal adipose tissue regions of interest were 209 pixels \pm 40 (standard deviation) (range, 36-260 pixels) for $o b /+$ mice and 1406 pixels \pm 475 (standard deviation) (range, 7444659 pixels) for $o b / o b$ mice.

The variance of signal intensity within epididymal adipose tissue $(V)$ that is dominated by the amount of susceptibility artifacts caused by the presence of compartmentalized USPIO particles $(16,17)$ was calculated as follows:

$$
V=\frac{\left(\mathrm{SD}^{2}\right)}{\mathrm{SI}_{\text {mean }}},
$$

where $\mathrm{SI}_{\text {mean }}$ is the mean signal intensity within the epididymal region of interest and SD is the standard deviation of signal intensity.

\section{Immunohistochemistry}

F4/80 was used as a marker of mature macrophages. Immunohistochemical detection of F4/80 was performed in epididymal adipose, formalin-fixed, paraffin-embedded tissue sections $(8 \mu \mathrm{m})$ by using a nondiluted antibody to F4/80 (Serotec MCA 497; AbD Serotec, Colmar, France) and a biotinylated secondary antibody (1/50, Serotec AAR10B; AbD Seortec), as previously described (3). The signal was amplified with phosphatase alkaline-conjugated streptavidin (1/20, Serotec; AbD Serotec), and alkaline phosphatase activity was revealed by using a fast red substratechromogen system (DakoCytomation, Trappes, France). The percentage of F4/80 positive cells within epididymal adipose tissue was determined by an author (V.D., a liver biology specialist with 8 years of expertise) by visually counting the positive F4/80 cells.

\section{RNA Extraction}

The induction of the messenger RNA expression of proinflammatory markers (CCl2, Tnf $\alpha$, and Emr1) in ob/ob mice was quantified as previously described 
(3). Total RNA was extracted from mice epididymal fat by using a kit (RNeasyH Lipid Tissue Mini Kit; Qiagen, Courtaboeuf, France). Quantitative reverse transcription polymerase chain reaction was performed with a LightCycler system (Roche Diagnostics, Meylan, France).

Oligonucleotide primer sequences of the mouse genes studied were as follows: mouse Rn18s sense 5' -ACCAGAGCGAAAGCATTTGCCA-3' and antisense: 5' ATCGCCAGTCGGCATCGTTTAT- ${ }^{\prime}$; mouse $\mathrm{CCl} 2$ sense 5'-GGGCCTGCTGTTCACAGTT- ${ }^{\prime}$ and antisense 5'-CCAGCCTACTCATTGGGAT-3'; mouse Emr1 sense 5'-CTTTGGCTATGGGCTTCCAGTC-3' and antisense 5'-GCAAGGAGGACAGAGTTTATCGTG-3'; and mouse Tnf sense $5^{\prime}$-AATGGCCTCCCTCTCATC A G T T - $3^{\prime}$ a n d a n t is e n s e 5'-CCACTTGGTGGTTTGCTACGA-3'.

Polymerase chain reaction amplified products were analyzed with a $2 \%$ agarose gel and sequenced.

\section{USPIO Detection and Quantification and Transmission Electron Microscopy}

Perls staining was used for localization of USPIO positive cells within excised epididymal adipose tissue.

Electron paramagnetic resonance (EPR) imaging was used for specific USPIO quantification on excised epididymal adipose tissue samples desiccated for 3 days at $80^{\circ} \mathrm{C}$. In contrast with atomic emission spectrometry, which measures all iron species in an organ (including endogenous heme and nonheme iron), EPR imaging performed at $300 \mathrm{~K}$ measures only the characteristic wide spectrum of superparamagnetic nanoparticles, because paramagnetic iron of deoxyhemoglobin has no signal at this temperature. The EPR spectrum of dried epididymal adipose tissue was recorded in a magnetic field strength range of $0-3300 \mathrm{G}(0-.33 \mathrm{~T})$ by using an EPR spectrometer (Varian E102; Agilent Technology, Massy, France) operating at $\mathrm{Q}$ band $(9.26 \mathrm{GHz})$. Because the absorption area is proportional to the total number of USPIOs in the EPR cavity $(18,19)$, the nanoparticle content in each sample can be computed with a detection sensitivity of $10^{-2} \mu \mathrm{g}$ of iron. Transmission electron microscopy was used to colocalize USPIO particles within adipose tissue macrophages.

For transmission electron microscopic analysis, $1-\mathrm{mm}^{3}$ pieces of freshly excised tissue were fixed with $2 \%$ glutaraldehyde in $0.1 \mathrm{~mol} / \mathrm{L}$ sodium $(\mathrm{pH}$ of 7.2) cacodylate buffer for 4 hours at room temperature and then postfixed with $1 \%$ osmium tetroxide containing $1.5 \%$ potassium cyanoferrate, stained with uranyl acetate $2 \%$ in water, gradually dehydrated in ethanol (30\%-100\%), and embedded in Epon. Thin sections $(70 \mathrm{~nm})$ of selected zones were collected onto 200 mesh copper grids and counterstained with lead citrate before examination with an electron microscope (Zeiss EM902; Carl Zeiss, Le Pecq, France) operated at 80 kV (MIMA2-UR1196 Genomics and Physiology of Lactation, INRA, Plateau Electron Microscopy, Jouy-en-Josas, France). Microphotographs were acquired with a camera (MegaView III CCD; Olympus, Münster, Germany) and analyzed with ITEM software (Eloïse-SARL, Roissy CDG, France) by an author (V.D.).

\section{Statistical Analysis}

Mean mice body weight, levels of epididymal adipose tissue inflammation depicted at immunohistochemistry, and expression of proinflammatory markers were compared in $o b / o b$ animals and their lean $o b /+$ littermates. An overall analysis of variance test was performed on variance of signal values, followed by Dunn multiple comparison tests. In addition, an analysis of variance test was applied comparing signal variance values for each age $(7,10$, and 14 weeks old), followed by pairwise comparisons between injected and noninjected $o b /$ $o b$ and $o b /+$ animals.

The variance of signal intensity within the epididymal adipose tissue observed at MR imaging was compared between ob/ob injected animals and controls. In addition, variance values observed in aging $o b / o b$ animals were compared. Similarly, variance values were compared between P904-injected $o b / o b$ animals and P904-injected $o b /+$ lean littermates of the same age.
The variance of signal intensity within the epididymal adipose tissue observed at MR imaging was correlated to body weight and expression of proinflammatory markers within adipose tissue. The signal intensity changes obtained at USPIO-enhanced MR imaging in the adipose tissue of aging $o b /$ ob mice were compared with those of their age-matched lean $o b /+$ littermates. Variance of signal values were also correlated to the percentage of F4/80 positive cells depicted at pathologic examination.

Last, the total amount of iron oxides within the epididymal adipose tissue measured at EPR imaging was correlated to the variance of signal observed at MR imaging, to the number of F4/80 positive cells, and to body weight.

Results were expressed as means \pm standard errors of the mean and were analyzed by using either the Mann-Whitney test or Student $t$ test as appropriate (PRISM 4.0, Macintosh; GraphPad Software, La Jolla, Calif). Correlations were performed by using the Pearson correlation test. $P$ value less than .05 was taken as the minimum level of significance.

\section{Results}

USPIO injection resulted in clear MR imaging susceptibility artifacts within epididymal adipose tissue in both $o b$ / $o b$ and $o b /+$ injected mice (Fig 2, A). The signal intensity variance was significantly higher in USPIO-injected $o b / o b$ mice than in noninjected $o b / o b$ mice at 7 weeks (286 \pm 49 [standard error of the mean] and $99 \pm 8$, respectively, $P$ $<.01)$ and at 10 weeks $(440 \pm 67$ and $138 \pm 9$, respectively, $P<.001)$. Sections of excised adipose tissue stained with Perls to detect iron confirmed that Perls staining colocalized with F4/80 positive adipose tissue macrophages in injected animals but not in noninjected controls (Fig 2, $B$ and $C$ ). Importantly, USPIO injections did not promote macrophage infiltration within adipose tissue. Indeed, there was no significant difference in F4/80 staining between injected and noninjected $o b / o b$ animals or $o b /+$ animals (Fig $2, B$ ). 


\section{Figure 2}

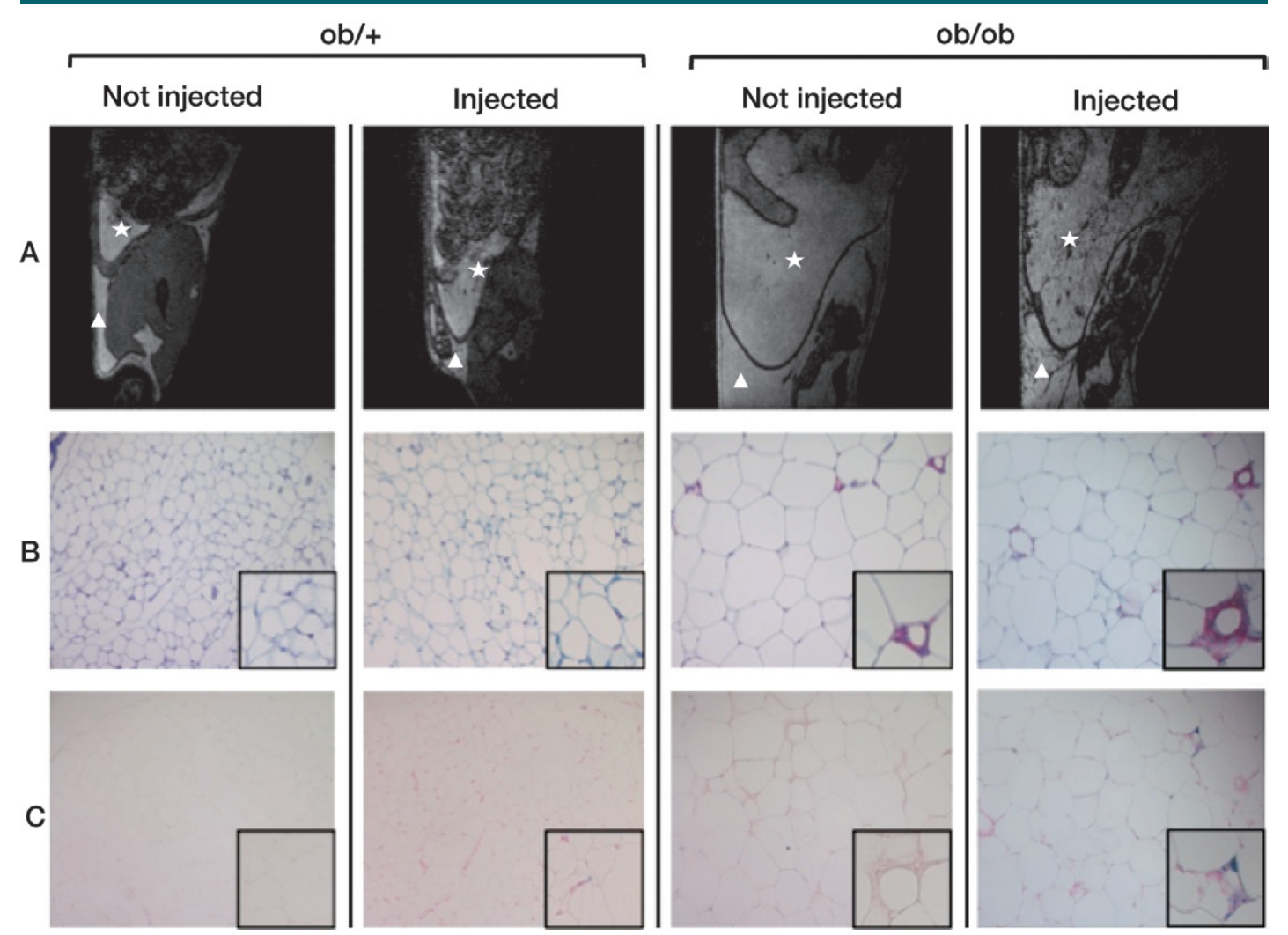

Figure 2: USPIO-enhanced MR imaging allows specific cellular imaging of adipose tissue macrophages. The levels of MR imaging susceptibility artifacts induced by USPIO injection parallel increased adipose tissue inflammation in obese mice. $A$, Sagittal three-dimensional T2*-weighted gradient-echo MR images in ob/+ and ob/ob animals, with and without injection of USPIO P904. Increased levels of susceptibility artifacts are noted within epididymal adipose tissue after P904 injection in ob/ob animals $(\triangle=$ subcutaneous adipose tissue, $i \frac{\hbar}{2}=$ epididymal adipose tissue). $B$, Immunostaining with F4/80 monoclonal antibody (original magnification, $\times 200$; inset: original magnification, $\times 400$ ) of epididymal adipose tissue of corresponding mice. F4/80 positive cells are pink stained. Increased levels of F4/80 positive cells are present in ob/ob animals. No difference is depicted between noninjected and injected animals of the same age and type. $C$, Perls staining (original magnification, $\times 200$; inset: original magnification, $\times 400$ ) on serial adipose tissue sections. Iron deposits are blue stained.

Susceptibility artifacts induced by USPIO uptake visually increased with age (Fig 3a). In keeping with these findings, significantly higher signal variance values were present within epididymal adipose tissue of USPIO-injected 14-week-old ob/ob animals compared with 10-week-old P904-injected ob/ob mice or 7-week-old P904-injected $o b /$ $o b$ animals (Fig $3 b$ ). Significantly higher variance values were detected within epididymal adipose tissue of USPIOinjected $o b / o b$ mice compared with USPIO-injected $o b /+$ mice at 7,10 , and 14 weeks of age (Fig 3b).

As expected, body weight of $o b / o b$ mice was significantly higher than that of their wild-type counterparts, with steady increase in weight with age and a parallel increase in macrophage-related adipose tissue inflammation (Fig 4, Fig E1 [online]) $(3,17)$. The variance of signal within epididymal adipose tissue at MR imaging induced by USPIO injection in $o b / o b$ mice correlated to both the number of $\mathrm{F} 4 / 80$ positive cells as assessed at immunohistochemistry $(r=0.60, P<.01)$ and to the messenger RNA expression of proinflammatory markers within adipose tissue, including CCl2, Tnf $\alpha$, and Emr1 RNA quantification $(r=0.55,0.56$, and 0.58 , respectively; $P<.01$ ).

EPR quantification demonstrated that the total number of P904 iron oxide nanoparticles within the epididymal adipose tissue was correlated to the variance of signal observed at MR imaging $(r=0.87, P<.0001)$ and to the number of $\mathrm{F} 4 / 80$ positive cells $(r$ $=0.88, P<.0001$ ) (Fig 5). The percentage of $F 4 / 80$ positive cells was also correlated to MR imaging signal variance $(r=0.72, P<.0001)$. Moreover, the increase in iron oxide quantification paralleled body weight gain $(r=0.97$, $P<.001)$. Last, transmission electron microscopic experiment results confirmed the presence of clustered USPIO particles within endosomes or lysosomes of adipose tissue macrophages (Fig E2 [online]). 
Discussion

Obesity is often considered a chronic low-grade inflammatory state similar to atherosclerosis or type II diabetes (20). Accumulation of immune cells in adipose tissue, particularly macrophages, is an important component of obesityassociated adipose tissue inflammation and contributes through increased systemic concentrations of inflammatory cytokines, including tumor necrosis factor $\alpha$, interleukin- 6 , and resistin, to the development of insulin resistance and metabolic syndrome (1). Quantification of these proinflammatory markers in the blood can be performed, but their direct and specific link to the intensity of macrophage-related adipose tissue inflammation can only be demonstrated by the simultaneous quantification of adipose tissue macrophages. USPIOenhanced MR imaging can depict macrophages within atherosclerotic walls and is nearing clinical use (21). Vessel walls with pronounced accumulation of macrophages appear more prone to instability and favor vessel thrombosis. Moreover, inflammation within steatotic liver has been reported to influence the degree of liver enhancement at MR imaging after USPIO injection (22). Hence, USPIO uptake within macrophages present within atherosclerotic vessels and liver can be detected at MR imaging. Current imaging techniques can assess the distribution and amount of adipose tissue throughout the body. Total visceral adipose tissue amount is indeed correlated to insulin resistance, steatosis, and atherosclerosis (23) and can be monitored by using T1-weighted MR imaging or spectroscopy (14). However, to our knowledge, MR imaging has not been used to monitor macrophage-related inflammation in the adipose tissue. This study demonstrated that cellular imaging by using USPIO-enhanced MR imaging allows detection, localization, and quantification of increasing levels of adipose tissue macrophage-related inflammation within visceral adipose tissue. Leptin-deficient mice with increasing weight showed differential accumulation of USPIO within adipose tissue, resulting in significant increase of the

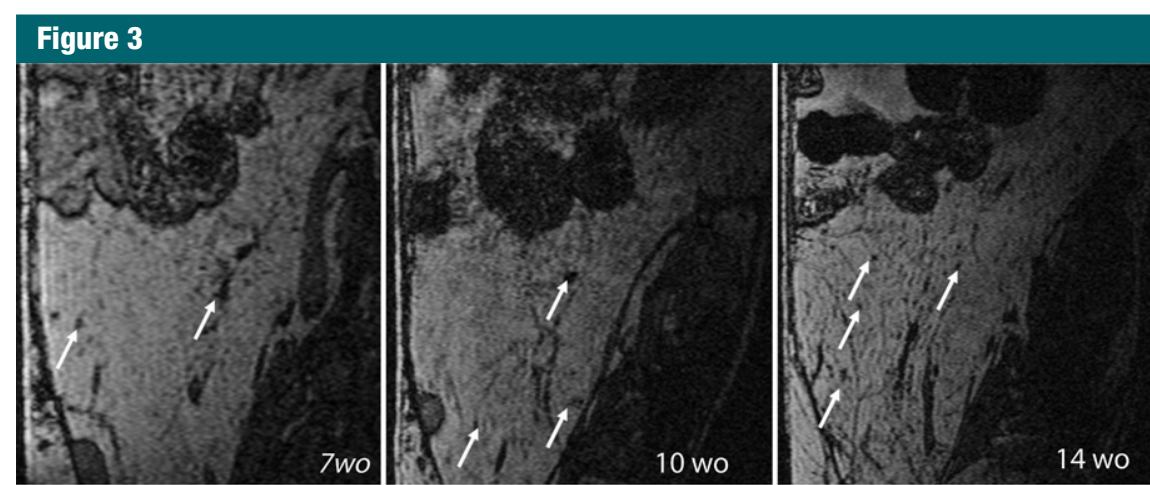

a.

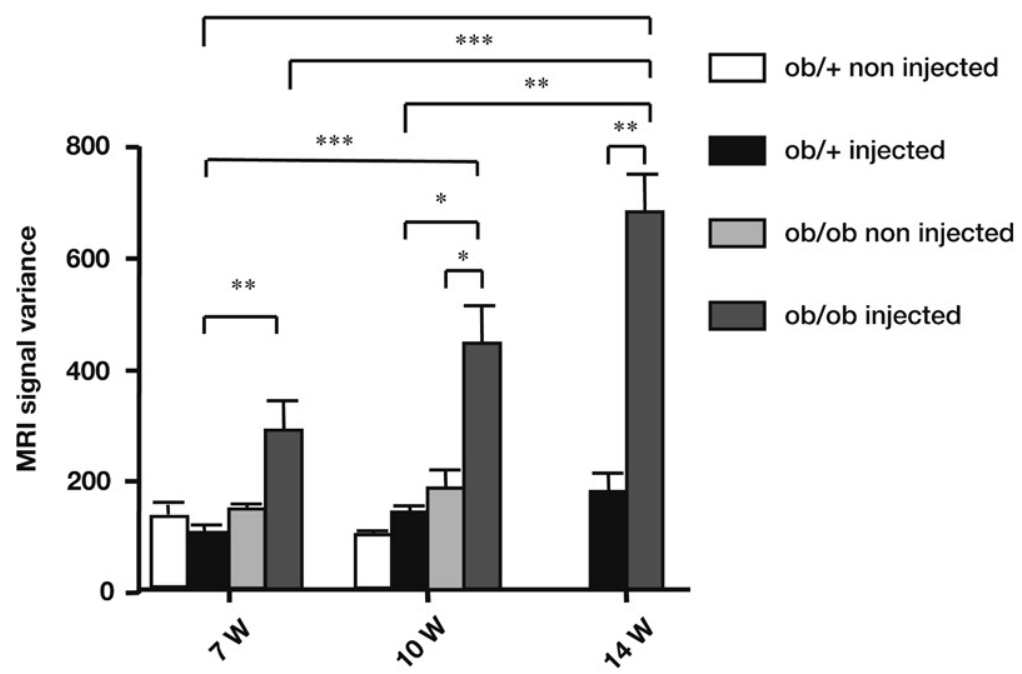

b.

Figure 3: USPIO-enhanced MR imaging allows detection of increasing levels of adipose tissue macrophage-related inflammation. The signal intensity variance within adipose tissue assessed at MR imaging after USPIO-particle injection correlates with the presence of an increased number of adipose tissue macrophages, increased body weight, and inflammation. (a) Three-dimensional sagittal T2*-weighted gradient-echo MR images of epididymal adipose tissue in three distinct ob/ob mice at 7, 10, and 14 weeks old (wo) show the increasing levels of susceptibility artifacts (arrows) within epididymal adipose tissue of elder mice consistent with the presence of USPIO. (b) Graph shows signal variance of epididymal adipose tissue depicted at MR imaging was significantly higher in USPIO-injected ob/ob mice than in noninjected ob/ $o b$ mice at 10 and 14 weeks $(W)$ of age. In addition, significantly higher variance values were detected within epididymal adipose tissue of USPIO-injected $o b / o b$ mice compared with USPIO-injected $o b /+$ mice of 7,10 , and 14 weeks of age $(*=P=.05, * *=P<.01, * * *=P<.001)$. Error bars $=$ standard deviation.

MR signal variance. P904 USPIOs were taken up by adipose tissue macrophages and were localized to the intracellular lysosomal compartments, thus creating easily detected local magnetic field distortions. Quantification of USPIO-loaded adipose tissue macrophages correlated to the messenger RNA expression of proinflammatory markers and to MR imaging signal variance in visceral adipose tissue of weight-increasing mice.
This study had several limitations. The experimental setup was restricted to a genetic mice model of obesity and to the investigation of one injected dose and one optimal time point after P904 injection. However, the $o b / o b$ animal model used in our study is not novel (24). In addition, the pathologic findings of this study confirmed data in the literature, showing early and increasing infiltration of adipose tissue by macrophages 


\section{Figure 4}

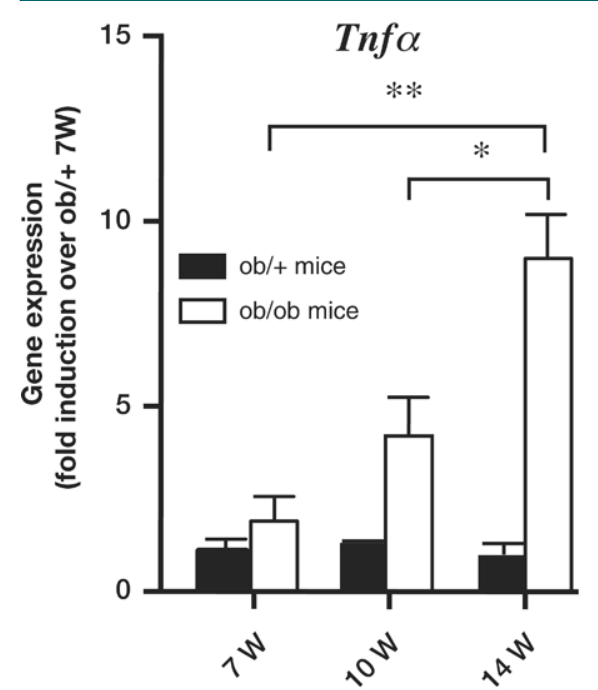

a.

b.

Figure 4: Graphs show changes in inflammation in aging $o b /+$ and $o b / o b$ animals. Aging $o b / o b$ mice showed significant induction of the messenger RNA expression of proinflammatory markers (a) Tnf $\alpha$ and (b) Emr1 in ob/ob animals $(*=P<.01, * *=P<.001)$. $W=$ weeks. Error bars $=$ standard deviation. as demonstrated with $\mathrm{F} 4 / 80+$ staining (3). The animals included in this study were not longitudinally followed-up by using MR imaging, despite the fact that MR imaging would potentially allow noninvasive and repeated examination of animals or humans with time. The design of our study required that pathologic data had to support each MR acquisition. Moreover, the sample size was small, with only 34 mice included in this study. Here, the kinetics of USPIO accumulation in adipose tissue macrophage was not investigated at short times after injection; but, the long-term biodistribution, biotransformation, and fate of P904 USPIO was assessed in a previous 3-month follow-up study (19). We chose to image at day 10 after injection of P904 because we found the highest accumulation of P904 in epididymal adipose tissue at this time point $(0.2 \%$ of injected

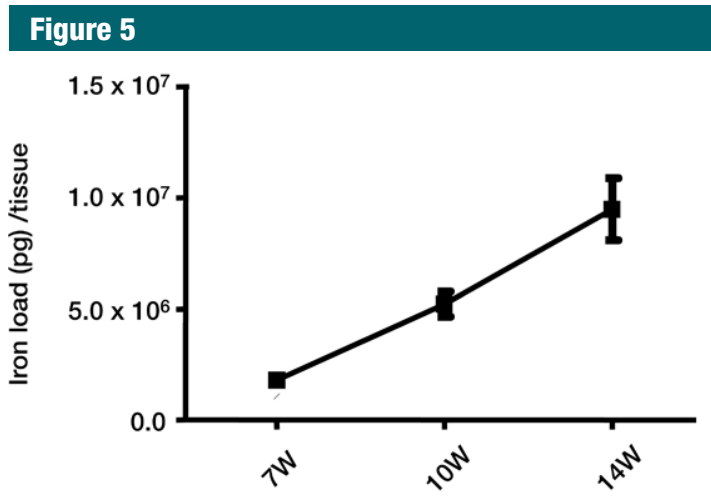

a.
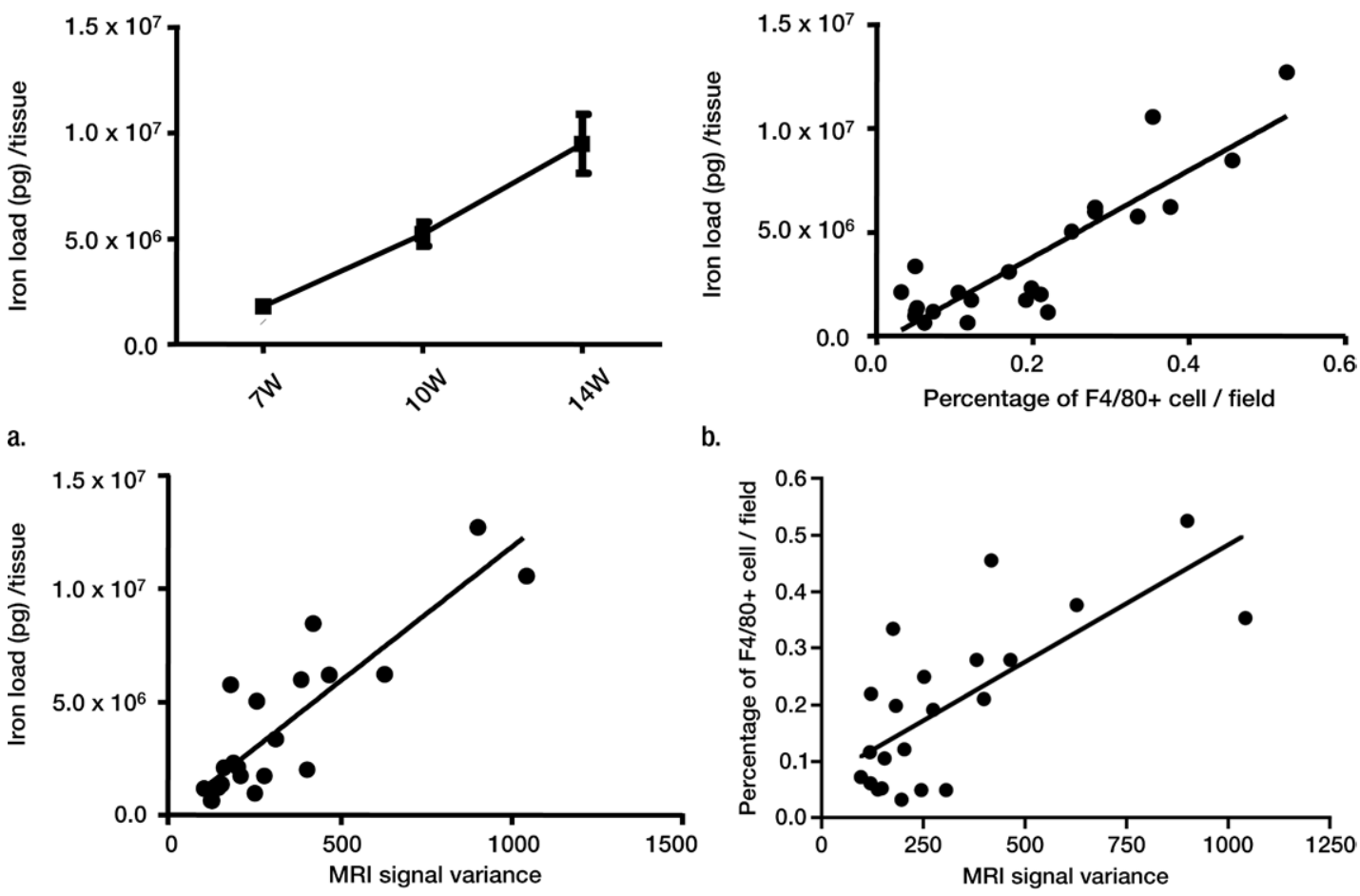

b.

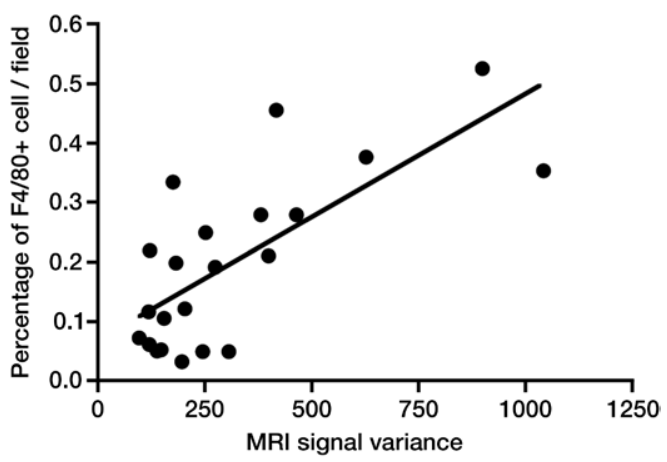

d.

Figure 5: Graphs show USPIO uptake within adipose tissue macrophages is significantly correlated to MR imaging signal variance, progressive aging, and adipose tissue inflammation. (a) Correlation between EPR iron quantification and aging in ob/ob animals $(r=$ $0.97, P<.001$ ). Error bars = standard deviation. (b) Correlation between EPR iron quantification and the percentage of F4/80 positive cells in ob/ob mice $(r=0.88, P<.0001)$. (c) Correlation between EPR iron quantification and (d) percentage of F4/80 positive cells and signal variance at MR imaging within epididymal adipose tissue in ob/ob animals $(r=0.87, P<.0001)$. 
dose), while the liver and spleen uptake corresponded to $30 \%$ and $1 \%$ of the injected dose, respectively (19). Moreover, the selected dose was $1000 \mu \mathrm{mol}$ of iron per kilogram, which is far beyond the dose to be tested in humans (because clinical trials and applications dosages of USPIO or superparamagnetic iron oxide are in the order of 12-45 $\mu \mathrm{mol}$ of iron per kilogram of body weight). Further experiments investigating the effect of reduced P904 dose injection are currently underway.

Showing that USPIO-enhanced MR imaging can depict adipose tissue macrophages directly involved in obesity-related disorder initiation and progression could be considered a first step in promoting a noninvasive screening method for at-risk obese patients. Combined with its potential for the detection of inflammation within atherosclerotic vessels and liver, USPIOenhanced MR imaging could potentially find a clinical application in the screening and follow-up of obese patients, potentially identifying those patients with increased adipose tissue inflammation at higher risk of comorbidities. To date, USPIO-enhanced MR imaging hence appears as an interesting noninvasive tool for the monitoring of inflammation accompanying obesity-related disorders in animal models of obesity. This could allow noninvasive longitudinal follow-up of macrophage-related inflammation, which is crucial when dealing with new therapeutic investigations (25).

Acknowledgment: The authors thank Thomas Decaens, MD, PhD, Hepatology Department, CHU Henri Mondor, Créteil, France, for his help in animal experiments.

Disclosures of Potential Conflicts of Interest: A.L. No potential conflicts of interest to disclose. S.D. No potential conflicts of interest to disclose. V.D. No potential conflicts of interest to disclose. M.P. No potential conflicts of interest to disclose. N.L. No potential conflicts of interest to disclose. M.L. No potential conflicts of interest to disclose. S.B. Financial activities related to the present article: Guerbet provided P904 product. Financial activities not related to the present article: author is Guerbet employee. Other relationships: none to disclose. S.M. No potential conflicts of interest to disclose. C.P. No potential conflicts of interest to disclose. G.A. No potential conflicts of interest to disclose. O.C. Financial activities related to the present article: institution received grant for M. Muehler from French Ministry of Foreign
Affairs. Financial activities not related to the present article: institution received grant from FP7 European commission; author receives payment for lectures from Schering Guerbet; author receives payment for development of educational presentations from Bracco. Other relationships: none to disclose. A.R. No potential conflicts of interest to disclose. A.M. No potential conflicts of interest to disclose. C.W. No potential conflicts of interest to disclose. S.L. Financial activities related to the present article: institution received grant from National Agency for Research. Financial activities not related to the present article: author and institution are board members/associate editor of American Journal of Physiology Cell Physiology; author is consultant (unrelated to the work); institution receives grants from the French national agency, author receives payment for lectures (unrelated to the work); institution has four patents unrelated to the work; author receives payment for development of educational presentation (unrelated to the work); author and institution receive money for travel, accommodations, and/or meeting expenses (unrelated to the work). Other relationships: none to disclose. F.G. No potential conflicts of interest to disclose.

\section{References}

1. Hotamisligil GS. Inflammation and metabolic disorders. Nature 2006;444(7121):860-867.

2. Hummasti S, Hotamisligil GS. Endoplasmic reticulum stress and inflammation in obesity and diabetes. Circ Res 2010;107(5):579-591.

3. Deveaux V, Cadoudal $\mathrm{T}$, Ichigotani $\mathrm{Y}$, et al. Cannabinoid CB2 receptor potentiates obesity-associated inflammation, insulin resistance and hepatic steatosis. PLoS ONE 2009;4(6):e5844

4. Gutierrez DA, Puglisi MJ, Hasty AH. Impact of increased adipose tissue mass on inflammation, insulin resistance, and dyslipidemia. Curr Diab Rep 2009;9(1):26-32.

5. Cancello R, Clément K. Is obesity an inflammatory illness? role of low-grade inflammation and macrophage infiltration in human white adipose tissue. BJOG 2006;113(10):1141-1147.

6. Fransson EI, Batty GD, Tabák AG, et al. Association between change in body composition and change in inflammatory markers: an 11-year follow-up in the Whitehall II Study. J Clin Endocrinol Metab 2010;95(12):53705374.

7. Goldberg RB. Cytokine and cytokine-like inflammation markers, endothelial dysfunction, and imbalanced coagulation in development of diabetes and its complications. J Clin Endocrinol Metab 2009;94(9):3171-3182.

8. Furuhashi M, Fucho R, Görgün CZ, Tuncman G, Cao H, Hotamisligil GS. Adipocyte/macrophage fatty acid-binding proteins contribute to metabolic deterioration through actions in both macrophages and adipocytes in mice. $\mathrm{J}$ Clin Invest 2008;118(7):2640-2650.

9. Wellen KE, Hotamisligil GS. Obesity-induced inflammatory changes in adipose tissue. J Clin Invest 2003;112(12):1785-1788.

10. Popko K, Gorska E, Stelmaszczyk-Emmel A, et al. Proinflammatory cytokines Il- 6 and TNF- $\alpha$ and the development of inflammation in obese subjects. Eur J Med Res 2010;15(suppl 2):120-122.
11. Morishige K, Kacher DF, Libby $\mathrm{P}$, et al High-resolution magnetic resonance imaging enhanced with superparamagnetic nanopar ticles measures macrophage burden in ath erosclerosis. Circulation 2010;122(17):17071715.

12. Truijers M, Fütterer JJ, Takahashi S, Heesakkers RA, Blankensteijn JD, Barentsz JO. In vivo imaging of the aneurysm wall with MRI and a macrophage-specific contrast agent. AJR Am J Roentgenol 2009;193(5):W437W441.

13. Sigovan M, Boussel L, Sulaiman A, et al. Rap id-clearance iron nanoparticles for inflam mation imaging of atherosclerotic plaque: initial experience in animal model. Radiology 2009;252(2):401-409.

14. Sigovan M, Bessaad A, Alsaid H, et al. As sessment of age modulated vascular inflammation in ApoE-/- mice by USPIO-enhanced magnetic resonance imaging. Invest Radiol 2010;45(11):702-707.

15. Pelleymounter MA, Cullen MJ, Baker MB, et al. Effects of the obese gene product on body weight regulation in ob/ob mice. Science 1995;269(5223):540-543.

16. Poirier-Quinot M, Frasca G, Wilhelm C, et al. High-resolution 1.5-Tesla magnetic resonance imaging for tissue-engineered constructs: a noninvasive tool to assess three-dimensional scaffold architecture and cell seeding. Tissue Eng Part C Methods 2010;16(2):185-200.

17. Levy M, Wilhelm C, Luciani N, et al. Nano magnetism reveals the intracellular clustering of iron oxide nanoparticles in the organism. Nanoscale 2011;3(10):4402-4410.

18. Wilhelm C, Gazeau F, Bacri JC. Magnetophoresis and ferromagnetic resonance of magnetically labeled cells. Eur Biophys J 2002;31(2):118-125.

19. Levy M, Luciani N, Alloyeau D, et al. Long term in vivo biotransformation of iron oxide nanoparticles. Biomaterials 2011;32(16):3988-3999.

20. Cancello R, Henegar C, Viguerie N, et al Reduction of macrophage infiltration and chemoattractant gene expression changes in white adipose tissue of morbidly obese subjects after surgery-induced weight loss. Diabetes 2005;54(8):2277-2286.

21. Trivedi RA, U-King-Im JM, Graves MJ, et al. In vivo detection of macrophages in human carotid atheroma: temporal dependence of ultrasmall superparamagnetic par ticles of iron oxide-enhanced MRI. Stroke 2004;35(7):1631-1635.

22. Asanuma T, Ono M, Kubota K, et al. Super paramagnetic iron oxide MRI shows defective Kupffer cell uptake function in non-alcoholic fatty liver disease. Gut 2010;59(2):258-266.

23. Weisberg SP, McCann D, Desai M, Rosen baum M, Leibel RL, Ferrante AW Jr. Obesity is associated with macrophage accu mulation in adipose tissue. J Clin Invest 2003;112(12):1796-1808.

24. Lindström P. The physiology of obese-hyper glycemic mice [ob/ob mice]. ScientificWorldJournal 2007;7:666-685.

25. Farnaud S. The evolution of the Three Rs. Altern Lab Anim 2009;37(3):249-254. 